\title{
Effects of reduced ultraviolet radiation on aqueous concentrations of dimethylsulfoniopropionate and dimethylsulfide during a microcosm study in the Lower St. Lawrence Estuary
}

\author{
Asma Sakka ${ }^{1, *}$, Michel Gosselin ${ }^{1}$, Maurice Levasseur ${ }^{2}$, Sonia Michaud $^{2}$, \\ Patrick Monfort ${ }^{3}$, Serge Demers ${ }^{4}$ \\ ${ }^{1}$ Département d'océanographie, Université du Québec à Rimouski, 310 allée des Ursulines, Rimouski, Québec, Canada G5L 3A 1 \\ ${ }^{2}$ Institut Maurice-Lamontagne, Ministère des Pêches et des Océans, CP 1000, Mont-Joli, Québec, Canada G5H 3 Z4 \\ ${ }^{3}$ Laboratoire d'Hydrobiologie Marine et Continentale, Unité Mixte de Recherche 'Écosystèmes lagunaires', \\ Université Montpellier II - CNRS (UMR 5556), Case 093, F-34095 Montpellier Cedex 05, France \\ ${ }^{4}$ INRS-Océanologie, 310 allée des Ursulines, Rimouski, Québec, Canada G5L 3A1
}

\begin{abstract}
In August 1994, microcosm experiments were conducted with the natural phytoplankton community from the Lower St. Lawrence Estuary. Canada, in order to determine the influence of ultraviolet radiation (UVR) on the production of dimethylsulfoniopropionate (DMSP) and dimethylsulfide (DMS). The planktonic community was exposed for $42 \mathrm{~h}$ to 2 different light regimes: natural light conditıons and LIVR reduced by $95 \%$ using UF3 filters. Throughout the experiments, flagellates dominated the algal community. During the first day, the production rate of DMS under reduced UVR was 4 times greater than under natural light conditions, suggesting a decrease in the loss rate of DMS under reduced UVR. There were no signifıcant effects of the light regimes on particulate DMSP (DMSP ), dissolved DMSP (DMSP $\left.P_{d}\right), D_{M S P}$ /chlorophyll a and DMSP $/$ total algal cell number ratios during the first $24 \mathrm{~h}$. During the second day, $\mathrm{DMSP}_{\mathrm{p}}$ concentrations, $\mathrm{DMSP}_{\mathrm{p}} / \mathrm{chlorophyll}$ a and $\mathrm{DMSP}_{\mathrm{p}} /$ total algal cell number ratios increased significantly under reduced $U V R$ whereas these variables decreased in the microcosms exposed to natural light conditions. These results suggest that the reduction of UVR favoured the accumulation of DMSP in algal cells. We conclude that the reduction of UVR affects the DMSP/DMS dynamics in seawater at 2 levels depending on the time frame considered: on a short-term basis ( $<24 \mathrm{~h}$ ), it increases the DMS concentration, probably by decreasing its removal; on a long-term basis ( $>24 \mathrm{~h}$ ), it increases algal DMSP content, probably by stimulating the synthesis and/or by inhibiting the excretion of DMSP.
\end{abstract}

KEY WORDS: Dimethylsulfıde - Dimethylsulfoniopropionate - Phytoplankton - Ultraviolet radiation. Photooxidatıon Bacteria Microcosms

\section{INTRODUCTION}

In the remote atmosphere, marine emissions of dimethylsulfide (DMS) play an important climatic role. They provide the major part of sulfate aerosols and

- Present address: GIROQ, Département de biologie, Université Laval, Québec, Québec, Canada G1K 7P4.

E-mail: aae264@agora.ulaval.ca cloud condensation nuclei (CCN) that increase the absorption and scattering of solar radiation (Charlson et al. 1987. Hegg et al. 1991, Lawrence 1993). DMS is produced from dimethylsulfoniopropionate (DMSP), an osmoregulatory molecule present in many microalgae (Challenger \& Simpson 1948, Reed 1983, Vairavamurthy et al. 1985, Dickson \& Kirst 1986, 1987a, b). DMSP is released in seawater during the senescent phase of blooms via cell autolysis (Nguyen et al. 1988, 
Turner et al. 1988, Matrai \& Keller 1993, 1994) and zooplankton grazing (Dacey \& Wakeham 1986, Belviso et al. 1990, 1993, Leck et al. 1990, Levasseur et al. 1994b, Cantin et al. 1996). Dissolved DMSP may then be converted into DMS by bacteria (Kiene \& Service 1991, Kiene 1992, Wolfe \& Kiene 1993, Wolfe et al. 1994). Bacterial degradation, photooxidation and sea-air ventilation represent the 3 major sinks for DMS (Brimblecombe \& Shooter 1986, Suylen et al. 1986, Zeyer et al. 1987, Gibson et al. 1990, Kiene \& Bates 1990, Malin et al. 1993, Kieber et al. 1996).

Results from recent studies indicate that DMSP synthesis and DMS production may be affected by light intensity. In Iaboratory studies, Karsten et al. (1990, 1992) demonstrated that DMSP quotas of green macroalgae from polar and temperate regions increase with light intensity. In the north-east tropical Atlantic Ocean, Belviso et al. (1993) found a relationship between light and DMSP accumulation in nanophytoplankton (most likely prymnesiophytes). Levasseur et al. (1994a) also attributed the increase in intracellular DMSP of ice microalgae to an increase in light intensity. In batch cultures, Vetter \& Sharp (1993) showed that increase in light intensity stimulates DMS production by the diatom Skeletonema costatum.

Changes in light spectral characteristics following the recent increase in ultraviolet radiation (UVR) caused by stratospheric ozone depletion (Watson 1988. Anderson et al. 1991, Smith et al. 1992, Kerr \& McElroy 1993) may also affect the dynamics of DMSP/DMS. From water collected on the coast of the North Sea, Brimblecombe \& Shooter (1986) demonstrated that an important part of marine DMS can be rapidly photooxidized by natural sunlight. In the Bellingshausen Sea, Antarctica, surface DMS concentrations decreased during peak daylight periods, possibly due to photooxidation (Crocker et al. 1995). Recently, Kieber et al. (1996) showed that, in the oligotrophic equatorial Pacific Ocean, direct photolysis by short wavelengths (<460 nm: blue and UV light) accounts for 7 to $40 \%$ of the DMS sink in the surface mixed layer (0 to $60 \mathrm{~m})$. Changes in UVR may also indirectly affect DMS production via their influence on the physiology and ecology of marine organisms, and their production of DMSP. Several works have shown that UVR influences the community composition of phytoplankton (Bidigare 1989, Karentz et al. 1991. Cullen et al. 1992, Bothwell et al. 1994). Since DMSP quotas are highly species-specific (Keller et al. 1989a, b, Keller 1991), these UVRinduced shifts in phytoplankton community may change DMSP production rates. UVR can also affect bacteria (Herndl et al. 1993, Lindell et al. 1995, Müller-Niklas et al. 1995) and zoo- plankton (Damkaer \& Dey 1983, Dey et al. 1988), 2 additional important components of the marine DMS cycle.

The goal of this study was to determine the influence of the natural levels of UVR on DMSP and DMS production by a natural coastal plankton community. To achieve this goal, seawater collected in the Lower St. Lawrence Estuary, Canada, was transported to microcosms and exposed to natural and reduced levels of UV radiation.

\section{MATERIAL AND METHODS}

Sampling and study sites. Microcosm experiments were conducted from 3 to 4 August 1994 at the Pointeau-Père field station of University of Quebec on the south shore of the Lower St. Lawrence Estuary (LSLE) (Fig. 1). Four plastic enclosures of $1.5 \mathrm{~m}$ depth and $200 \mathrm{l}$ volume were filled on 3 August at 01:00 h with LSLE seawater pumped from the pier of the Maurice Lamontagne Institute $\left(68^{\circ} 20^{\prime} \mathrm{W}_{i} 48^{\circ} 35^{\prime} \mathrm{N}\right)$ (Fig. 1). Before filling the enclosures, the seawater was filtered onto a Nytex filter $(202 \mu \mathrm{m})$ to remove mesozooplankton. The microcosms were placed in an enclosure cooled with seawater pumped from $10 \mathrm{~m}$ depth in front of the shore station in order to simulate in situ temperature conditions. Water temperature in the different microcosms was measured every $6 \mathrm{~h}$. Immediately after their filling, 2 microcosms were covered with $4.5 \mathrm{~mm}$ thick neutral Plexiglas filters that cut $10 \%$ of 3 bandwidths of light, PAR (photosynthetically available radiation, 400 to $700 \mathrm{~nm}), \mathrm{UV}-\mathrm{A}(320$ to $400 \mathrm{~nm})$ and UV-B (280 to $320 \mathrm{~nm})$, while the 2 others were covered with $4.5 \mathrm{~mm}$ thick UF3 filters (Rohm and Haas Company, UK) which cut $10 \%$ of incident PAR, $95 \%$ of incident UV-A and $98 \%$ of in-

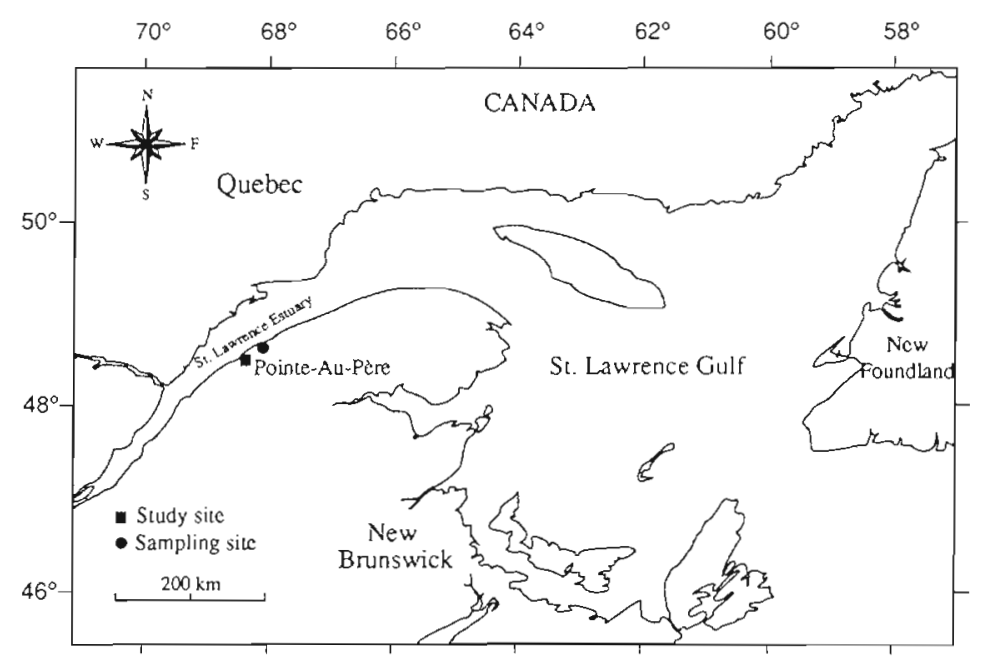

Fig. 1. Location of study and sampling sites 
cident UV-B. Incident irradiance (UV and PAR, 280 to $700 \mathrm{~nm}$ ) was measured with a IL 1700 radiometer (Inter National Light Company) equipped with detectors to measure PAR, UV-A and UV-B. Each light sensor was calibrated at the National Institute of Standards and Technology, Newburyport, MA, USA.

Water samples were collected every 6 h. Before sampling, the microcosms contents were mixed delicately with a paddle, then $10 \mathrm{l}$ of water was collected from each enclosure and temporarily kept in a black bottle For each sample, we determined in duplicate the concentrations of nutrients (nitrate + nitrite and phosphate), particulate DMSP (DMSP $)$ and dissolved DMSP $\left(\right.$ DMSP $_{d}$ ), free DMS and chlorophyll a (chl a) and phytoplankton, microzooplankton and bacterial cell numbers.

Laboratory analyses. For nutrient determination (nitrate + nitrite and phosphate), a $50 \mathrm{ml}$ subsample was filtered through a Whatman GF/F glass-fiber filter and the filtrate was frozen at $-20^{\circ} \mathrm{C}$ for later analysis using a Technicon Auto Analyzer (Strickland \& Parsons 1972)

For DMSP $_{\mathrm{p}}$ determination, two $250 \mathrm{ml}$ subsamples were filtered on Whatman GF/F filters (pressure $<178 \mathrm{~mm} \mathrm{Hg}$ ). The filters were then placed in serum bottles filled with $18.5 \mathrm{ml}$ of distilled water and $0.8 \mathrm{ml}$ of $5 \mathrm{~mol} \mathrm{l}^{-1} \mathrm{KOH}$ to convert DMSP into DMS (Challenger \& Simpson 1948). For DMSP + free DMS determination, two $50 \mathrm{ml}$ serum bottles were filled with $46 \mathrm{ml}$ of the filtrate and $2 \mathrm{ml}$ of $5 \mathrm{~mol} \mathrm{l}^{-1} \mathrm{KOH}$. For free DMS determination, 2 serum bottles were filled with $115 \mathrm{ml}$ of the filtrate and $5 \mathrm{ml}$ of distilled water. All serum bottles were immediately sealed with a Teflon-faced serum cap and kept in the dark at $4^{\circ} \mathrm{C}$ until analysis. DMS samples were analyzed less than $2 \mathrm{~h}$ after the sampling while both DMSP samples were frozen at $-20^{\circ} \mathrm{C}$ and analyzed during the next week. In all cases (free DMS,

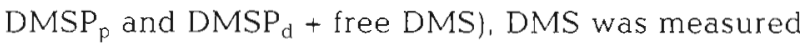
on a Varian 3400 gas chromatograph equipped with a flame photometric detector and a Chromosil 330 Teflon column (Supelco) according to a modified method of Leck \& Bågander (1988). Samples were sparged with $\mathrm{N}_{2}$ gas (30 ml min ${ }^{-1}$ ) in a heated bubbling chamber $\left(70^{\circ} \mathrm{C}\right)$. The extracted gases were then cryotrapped in a Teflon loop submerged in liquid nitrogen. The Teflon loop was subsequently heated $\left(70^{\circ} \mathrm{C}\right)$, releasing the extracted gas onto the GC column

For chlorophyll a determination, $1000 \mathrm{ml}$ subsamples were filtered through Whatman GF/F filters, which were subsequently frozen in liquid nitrogen. Each filter was ground in $4 \mathrm{ml}$ of a solution of $98 \%$ methanol and $2 \%$ ammonium acetate, and the extract centrifuged at $3000 \mathrm{rpm}$ for $5 \mathrm{~min}$. The supernatent was filtered on a Gelman filter (Acrodisc CR PTFE syringe, $0.2 \mu \mathrm{m}$ ) and the filtrate was analyzed using reversed- phase HPLC (High Performance Liquid Chromatography) (Wright et al. 1991).

Subsamples were fixed with the acidic Lugol's solution (Throndsen 1978) for the identification and counting of phytoplankton and microzooplankton with an inverted microscope (Utermöhl 1931). For direct bacterial counts, subsamples $(10 \mathrm{ml})$ were fixed by addition of $1 \mathrm{ml}$ of formaldehyde (final concentration $3.7 \%$ ) and held at $4^{\circ} \mathrm{C}$. The bacterial cells were stained for $1 \mathrm{~h}$ at $4^{\circ} \mathrm{C}$ with DAPI $\left(4^{\prime}, 6\right.$-diamidino-2-phenylindole) (Sigma) at final concentration of $2.5 \mu \mathrm{g} \mathrm{ml}^{-1}$ (Porter \& Feig 1980). Then, they were filtered onto a Nuclepore membrane filter ( $0.2 \mu \mathrm{m} ; 47 \mathrm{~mm}$; black filter) and counted using a Leitz epifluorescence microscope equipped with a $100 \mathrm{~W}$ mercury lamp and filters to accommodate excitation and emission wavelengths for DAPI.

Statistical analyses. Before undertaking the different parametric statistical tests, the normality of distribution and the homogeneity of variance were verified with the test of conformity of Kolmogorov-Smirnov (Zar 1984) and the test of Hartley (test of the $F_{\max }$ ) (Winer 1971), respectively. No transformation was required since the normality and the homoscedacity were respected.

The analysis of variance (ANOVA) with repeated measures was used for the comparison of averages (Zar 1984). The null hypothesis $\left(\mathrm{H}_{0}\right)$ stipulates that averages of a measured variable are equal between both light regimes. The ANOVA with repeated measures does not test the interaction effects between the sampling time and the UVR treatment (Zar 1984). The ANOVA was completed by a posteriori contrast test, the test of Fisher's LSD (Least Significant Difference) (Zar 1984). This test allows the identification of averages that are significantly different between the 2 experimental conditions.

Simple linear regression (Zar 1984) was used to estimate the relationship between biogenic sulfur (DMSP $p$, DMSP $_{\mathrm{d}}$ and DMS) and sampling time under the natural and reduced light regimes during the first $24 \mathrm{~h}$ of the experiment.

Spearman's rank correlations (Zar 1984) were also used to determine the correlation between the biogenic sulfur pools, the different biological variables and the sampling time under both light regimes.

\section{RESULTS}

\section{Variations of irradiance, water temperature and nutrients}

Temporal variations of light intensities under neutral and UF3 filters are presented in Fig. 2. During the first day, microcosms covered with neutral filters (microcosms 

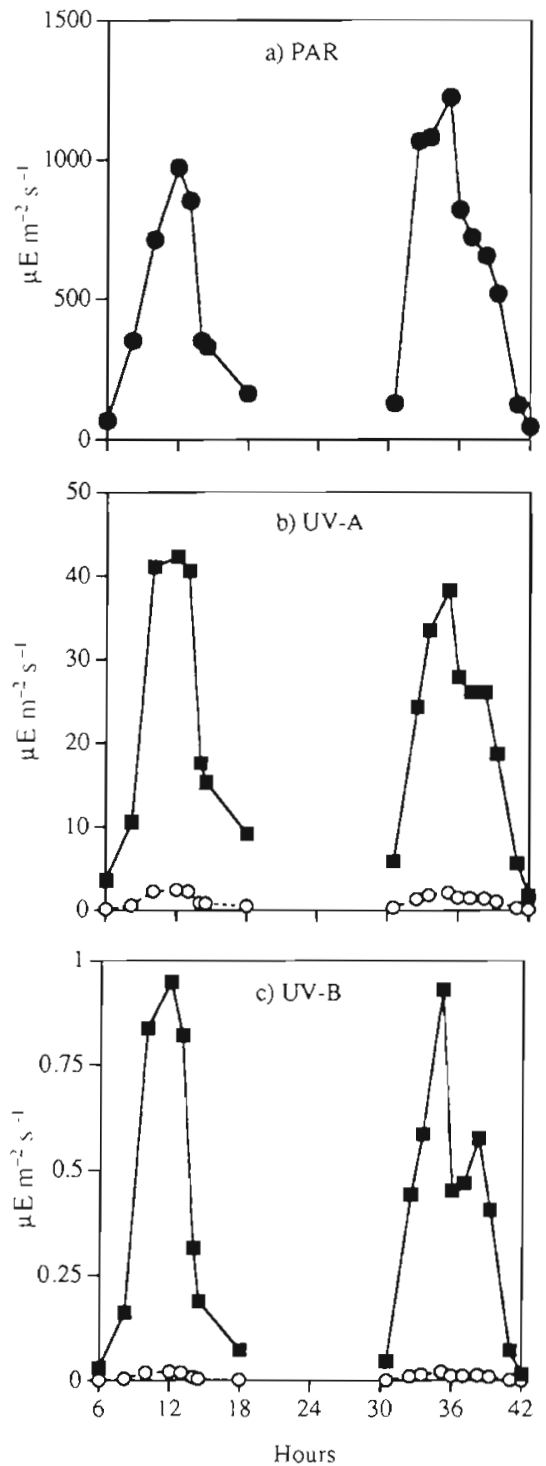
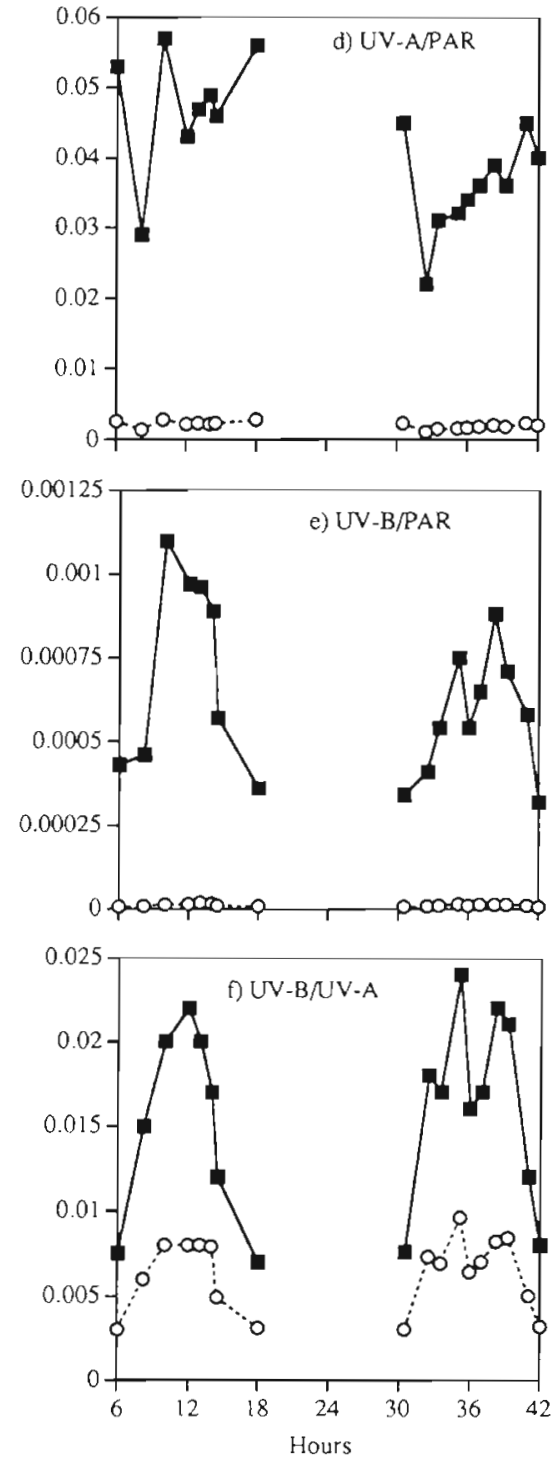

Fig. 2. Temporal variations of (a) PAR (photosynthetically available radiation; 400 to $700 \mathrm{~nm}$ ), (b) UV-A (320 to $400 \mathrm{~nm})$, (c) UVB (280 to $320 \mathrm{~nm}$ ). (d) UV-A/PAR ratio, (e) UV-B/PAR ratio and (f) UV-B/UV-A ratio under neutral density $(\bullet, \mathbf{\bullet})$ and UF3 (O) filters. In (a), PAR is the same under both light regimes exposed to natural light conditions) received maximal PAR, UV-A and UV-B intensities of $975,42.50$ and $0.95 \mu \mathrm{E} \mathrm{m}^{-2} \mathrm{~s}^{-1}$, respectively (Fig. $2 \mathrm{a}, \mathrm{b}, \mathrm{c}$ ). During this day, the maximum value of UV-A/PAR and UV-B/PAR ratios, obtained under natural light conditions, was 0.057 and 0.001 , respectively (Fig $2 \mathrm{~d}$, e). These maximum values were observed at 10:00 $\mathrm{h}$. On the other hand, the maximum value of UV-B/UV-A ratio $(0.022)$ was obtained at 12:00 h (Fig. 2f). During the second day, maximum intensities of PAR $\left(1224 \mu \mathrm{E} \mathrm{m} \mathrm{m}^{-2} \mathrm{~s}^{-2}\right)$, UV-A (38.50 $\left.\mu \mathrm{E} \mathrm{m}^{-2} \mathrm{~s}^{-1}\right)$ and UV-B $\left(0.93 \mu \mathrm{E} \mathrm{m}^{-2} \mathrm{~s}^{-1}\right)$ under neutral filters were measured at 11:10 h (Fig. 2a, b, c). At this time, the UV-B/UV-A ratio was also maximum (0.024) under the natural light regime (Fig. 2f). Under the same light conditions, the maximum value of the UVA/PAR (0.045) and UV-B/PAR (0.0009) ratios was reached at $6: 30$ and at $14: 15$ h, respectively (Fig. $2 d$, e).
UF3 filters cut $10 \%$ of the incident PAR but 95 and $98 \%$ of incident UV-A and UV-B, respectively (Fig. 2a, $b, c)$. During the 2 days of the experiment, UV-A and UV-B intensities, under UF3 filters, did not exceed 2.35 and $0.02 \mu \mathrm{E} \mathrm{m}^{-2} \mathrm{~s}^{-1}$, respectively (Fig. $2 \mathrm{~b}, \mathrm{c}$ ).

The total incident irradiance (UV and PAR) received by the microcosms exposed to the natural light regime during the first and the second day was $23.7 \mathrm{E} \mathrm{m}^{-2} \mathrm{~d}^{-1}$ (4.8 $\mathrm{MJ} \mathrm{m}^{-2} \mathrm{~d}^{-1}$ ) and $34.0 \mathrm{E} \mathrm{m}^{-2} \mathrm{~d}^{-1}\left(6.9 \mathrm{MJ} \mathrm{m}^{-2} \mathrm{~d}^{-1}\right)$, respectively. Under reduced $U V R$, the total incident irradiance was $22.8 \mathrm{E} \mathrm{m}^{-2} \mathrm{~d}^{-1}$ (4.5 $\mathrm{MJ} \mathrm{m}^{-2} \mathrm{~d}^{-1}$ ) and $33.0 \mathrm{E} \mathrm{m}^{-2} \mathrm{~d}^{-1}\left(6.6 \mathrm{MJ} \mathrm{m}^{-2} \mathrm{~d}^{-1}\right)$ during the first and the second day, respectively.

Temporal variations of the water temperature and nutrients concentrations (nitrate + nitrite and phosphate) are presented in Fig. 3. Water temperature increased from 11.3 to $15.5^{\circ} \mathrm{C}$ in all microcosms during 

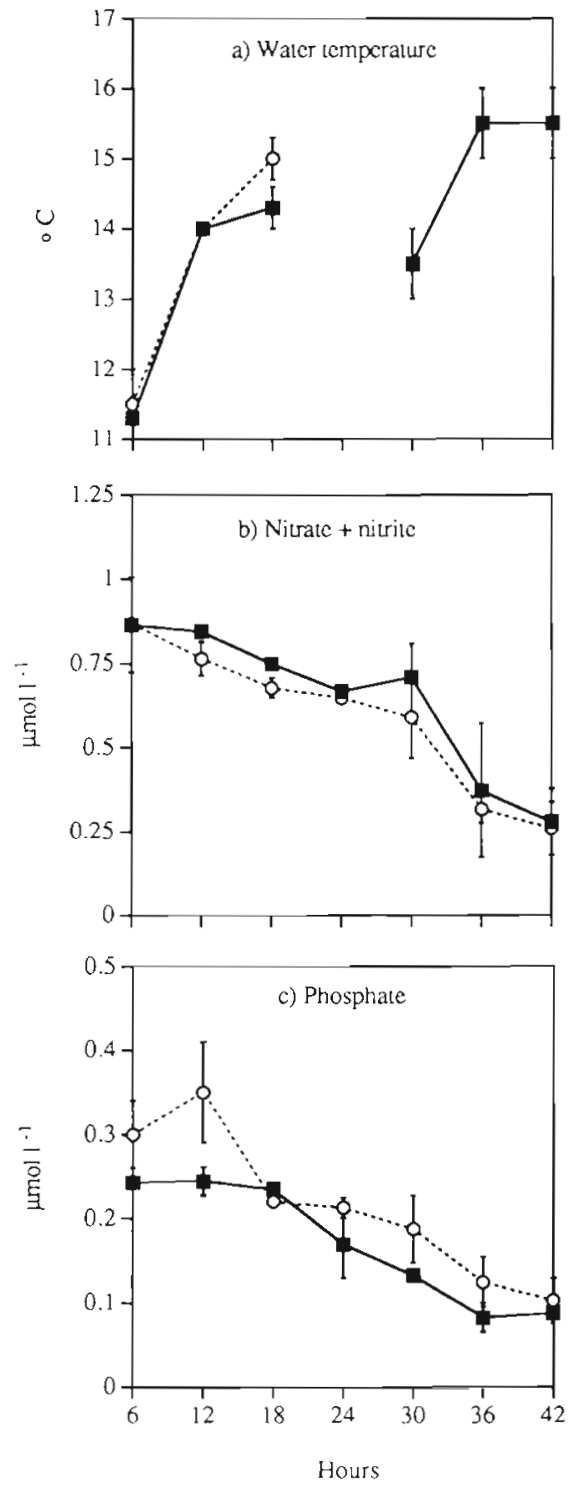

Fig. 3. Temporal variations of (a) water temperature, (b) nitrate + nitrite concentration and (c) phosphate concentration under natural (a) and reduced (o) UVR (average \pm standard deviation of duplicates)

the 2 days of the experiment (Fig. 3a). An ANOVA analysis with repeated measures showed, however, no significant difference in mean water temperature between both light regimes (Table 1). Concentrations in nitrate + nitrite and in phosphate were, respectively, 0.86 and $0.27 \mu \mathrm{mol} \mathrm{l}^{-1}$ at the beginning of the sampling period and decreased to values of $0.30 \mu \mathrm{mol} \mathrm{l}^{-1}$ for nitrate + nitrite and $0.10 \mu \mathrm{mol} \mathrm{l}^{-1}$ for phosphate at the end of the experiment (Fig, 3b,c). Concentrations of nitrate + nitrite and of phosphate were similar in microcosms exposed to both light conditions (Table 1). Hence, changes in biological and chemical variables measured between both treatments (see below) cannot
Table 1 Analyses of variance (ANOVA) with repeated measures concerning the effects of sampling time and UVR treatment on water temperature, nutrients (nitrate + nitrite and phosphate), chlorophyll a, total phytoplankton, flagellate, dinoflagellate, diatom and Cryptomonas spp. abundances, bacterial and ciliate abundances, DMSP ${ }_{p}$ DMSP per chlorophyll $a$ and DMSP per total algal cell number, DMSP and DMS. 'Significant at $5 \%$, ' signiticant at $1 \%$ and $\cdots$ significant at $0.1 \%$. ns: non significant

\begin{tabular}{|c|c|c|}
\hline \multirow[t]{2}{*}{ Variables } & \multicolumn{2}{|c|}{ Sources of variation } \\
\hline & Sampling time & UVR treatment \\
\hline Water temperature & $\ldots$ & ns \\
\hline Nitrate + nitrite & $\ldots$ & ns \\
\hline Phosphate & .. & ns \\
\hline Chlorophyll a & $\ldots$ & ns \\
\hline Total phytoplankton & $\ldots$ & ns \\
\hline Flagellates & $\ldots$ & ns \\
\hline Dinoflagellates & $\cdot$ & ns \\
\hline Diatoms & . & ns \\
\hline Cryptomonas spp. & $\ldots$ & ns \\
\hline Bacteria & $\cdot$ & ns \\
\hline Ciliates & . & ns \\
\hline $\operatorname{DMSP}_{\mathrm{p}}$ & $\ldots$ & .. \\
\hline $\mathrm{DMSP}_{\mathrm{p}} / \mathrm{algal}$ cell & . & . \\
\hline DMSP $_{p} /$ chlorophyll a & . & . \\
\hline DMSP $_{d}$ & .. & .. \\
\hline DMS & $\ldots$ & $\ldots$ \\
\hline
\end{tabular}

be explained from changes in water temperature or in ambient nutrients.

\section{Variations in phytoplankton biomass, abundance and species composition}

Temporal variations in chlorophyll $a$, total algal cell number and abundance of the different taxa (flagellates, dinoflagellates and diatoms) are presented in Fig. 4 . In the 4 microcosms, chlorophyll a concentration and total algal cell number increased during the experiment from 1.35 to $3.75 \mathrm{\mu g} \mathrm{l}^{-1}$ and from $0.60 \times 10^{6}$ to $1.90 \times 10^{6}$ cells $^{-1}$ (Fig. $4 \mathrm{a}$, b). Flagellate abundance

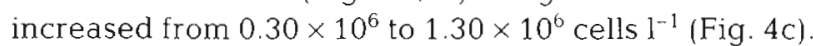
This group was dominated by Cryptomonas spp.,

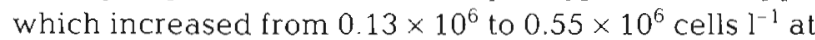
the end of the experiment (Fig. $4 \mathrm{~d}$ ). The abundance of dinoflagellates increased from $0.17 \times 10^{6}$ to $0.50 \times 10^{6}$ cells $\mathrm{l}^{-1}$ (Fig. 4e). This group was dominated by Katodynium spp. Diatoms, which were dominated by Thalassiosira spp., increased from $0.10 \times 10^{6}$ to $0.23 \times 10^{6}$ cells $\mathrm{l}^{-1}$ (Fig. 4f). Abundances of the different phytoplankton groups (flagellates, dinoflagellates and diatoms) were not significantly affected by reduced UVR (Table 1). There was no important change in the species composition of the phytoplankton assemblage during the experiment in either treatment. Flagellates 

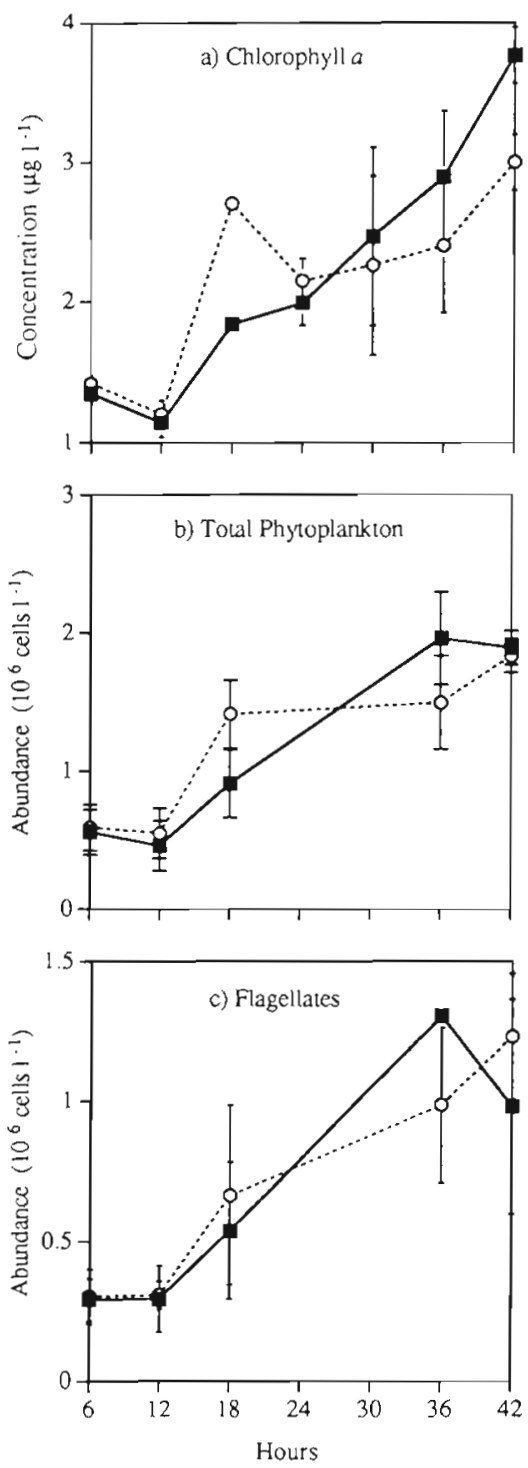
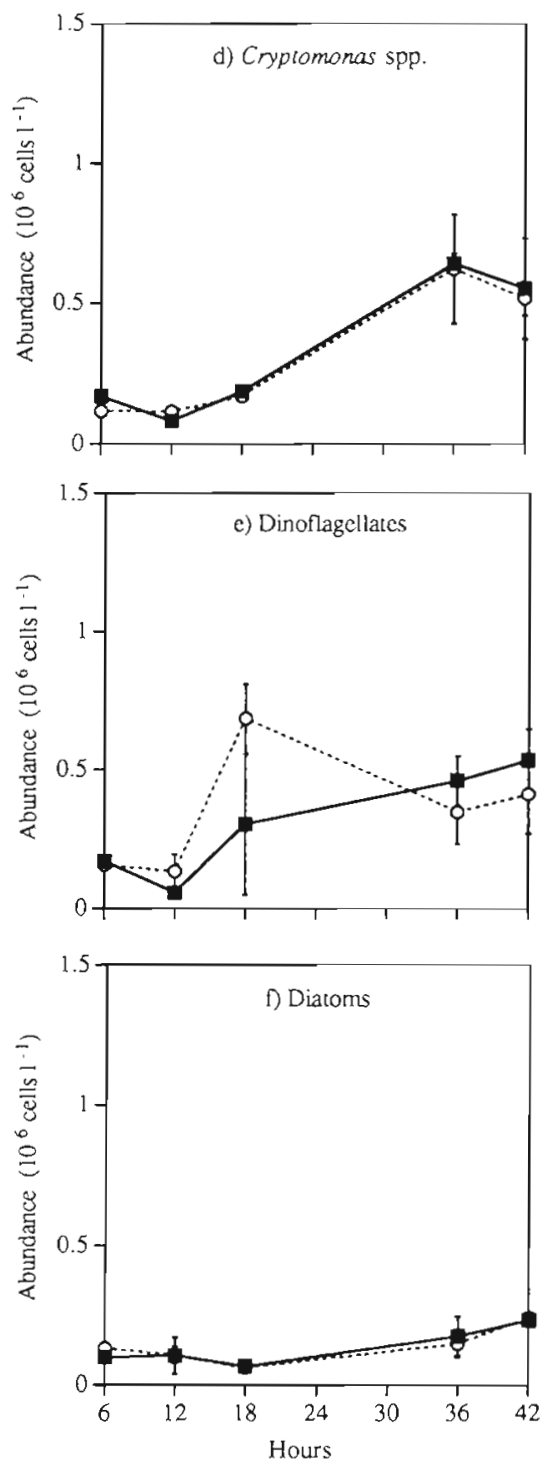

Fig. 4. Temporal variations of (a) chlorophyll a concentration, (b) total phytoplankton abundance, (c) flagellate abundance, (d) Cryptomonas spp. abundance, (e) dinoflagellate abundance and (f) diatom abundance under natural (a) and reduced (0) UVR (average \pm standard deviation of duplicates) dominated the phytoplankton community, representing approximately $60 \%$ of the total algal cell number. Dinoflagellates and diatoms represented 20 to $34 \%$ and 6 to $20 \%$ of the total algal abundance, respectively.

\section{Variations in $\mathrm{DMSP}_{\mathrm{p}}, \mathrm{DMSP}_{\mathrm{d}}$ and DMS}

Temporal variations in DMSP $_{\mathrm{p}}$, DMSP $_{\mathrm{d}}$ and free DMS are presented in Fig. 5. At the beginning of the sampling period, DMSP concentrations were approximately $109 \mathrm{nmol} \mathrm{l}^{-1}$ in the 4 microcosms (Fig. 5a). During the first day, $\mathrm{DMSP}_{\mathrm{p}}$ concentrations increased similarly under the natural and reduced light regimes at rates of 9.30 and $9.90 \mathrm{nmol} \mathrm{l}^{-1} \mathrm{~h}^{-1}$, respectively (Fig. 5a, Table 2). After $24 \mathrm{~h}, \mathrm{DMSP}_{\mathrm{p}}$ concentrations measured under reduced UVR began to increase as compared to those measured under the natural light regime (Fig. 5a). Under natural light conditions, DMSP concentrations remained relatively stable around $285 \mathrm{nmol} \mathrm{I}^{-1}$ between 24 and $36 \mathrm{~h}$ and then decreased to $220 \mathrm{nmol} \mathrm{l}^{-1}$ at the end of the experiment (Fig. 5a). On the other hand, DMSP levels measured under reduced UVR continued to increase during the second day (Fig. 5a). At 42 h, DMSP concentrations measured under reduced UVR reached a value 2.5 times greater than under the natural light regime (Fig. 5a). Under both light conditions, DMSP $_{\mathrm{p}}$ concentration was correlated with chlorophyll a concentration and flagellate abundance (Tables 3 \& 4). Under the reduced UVR regime, $D M S P_{p}$ concentration was also correlated with the abundance of the flagellate Cryptomonas spp. (Table 4). 
Table 2. Least squares linear regression statistics between biogenic sulfur (DMSP . DMSP $_{d}$ and DMS) and sampling time under the natural and reduced light regimes during the first $24 \mathrm{~h}$ of the experiment. For the regressions, only the 4 first points of Fig. $5 \mathrm{a}$, b, c are used. $\cdot 0.01<\mathrm{p} \leq 0.05, \cdots 0.001<\mathrm{p} \leq 0.01, \cdots \mathrm{p} \leq 0.001$

\begin{tabular}{|c|c|c|c|c|c|c|}
\hline & \multicolumn{2}{|c|}{ Slope $\left(\mathrm{nmol} \mathrm{I}^{-1} \mathrm{~h}^{-1}\right)$} & \multicolumn{2}{|c|}{ Intercept $\left(\mathrm{nmol} \mathrm{I}^{-1}\right)$} & \multicolumn{2}{|c|}{ Correlation coefficient } \\
\hline & $\begin{array}{l}\text { Natural } \\
\text { UVR }\end{array}$ & $\begin{array}{c}\text { Reduced } \\
\text { UVR }\end{array}$ & $\begin{array}{c}\text { Natural } \\
\text { UVR }\end{array}$ & $\begin{array}{c}\text { Reduced } \\
\text { UVR }\end{array}$ & $\begin{array}{l}\text { Natural } \\
\text { UVR }\end{array}$ & $\begin{array}{c}\text { Reduced } \\
\text { UVR }\end{array}$ \\
\hline $\mathrm{DMSP}_{p}$ and sampling time & 9.30 & 9.90 & 60 & 71 & $0.94^{*}$ & $0.96 \cdots$ \\
\hline DMSP $_{n}$ and sampling time & 1.30 & 1.25 & 46 & 40 & $0.78^{\circ}$ & $0.72^{\circ}$ \\
\hline DMS and sampling time & 0.15 & 0.58 & 13 & 11 & $0.95 \cdots$ & $0.99 \cdots$ \\
\hline
\end{tabular}
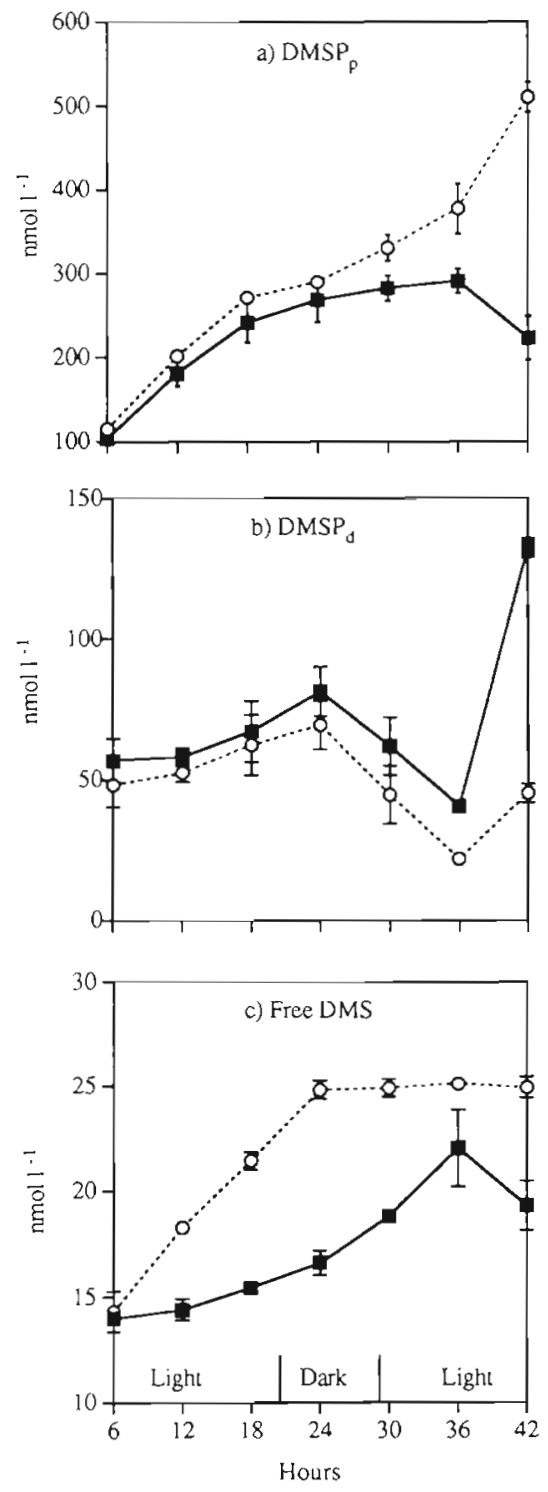

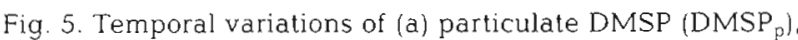
(b) dissolved DMSP (DMSP ${ }_{d}$ ) and (c) free DMS under natural (a) and reduced (O) UVR (average \pm standard deviation of duplicates)
Table 3. Spearman's rank coefficients of correlation between biogenic sulfur, different biological variables and sampling time under the natural light regime for the whole duration of the experiment (DMSP $_{p}$, DMSP $_{d}$, DMS, chl a and bacterial abundance, $n=14$; for the other variables, $n=10$ ). $\cdot 0.01<p \leq$ $0.05, \cdots 0.001<p \leq 0.01, \cdots p \leq 0.001$

\begin{tabular}{|c|c|c|c|}
\hline Natural UVR & $\mathrm{DMSP}_{p}$ & $\mathrm{DMSP}_{\mathrm{d}}$ & DMS \\
\hline $\mathrm{DMSP}_{d}$ & -0.068 & & \\
\hline DMS & $0.758^{\cdots}$ & -0.024 & \\
\hline Chl a & $0.547^{\circ}$ & 0.236 & $0.842 \cdots$ \\
\hline Total phytoplankton & $0.709^{\circ}$ & -0.097 & $0.709^{\circ}$ \\
\hline Flagellates & $0.806^{\cdots}$ & -0.353 & $0.806^{\cdots}$ \\
\hline Dinoflagellates & 0.467 & 0.347 & 0.636 \\
\hline Diatoms & 0.030 & 0.347 & 0.030 \\
\hline Cryptomonas spp. & 0.632 & 0.073 & $0.806^{\circ}$ \\
\hline Katodynium spp. & 0.600 & 0.226 & 0.644 \\
\hline Thalassiosira spp. & 0.273 & 0.122 & 0.624 \\
\hline Bacteria & -0.246 & 0.582 & -0.246 \\
\hline Ciliates & -0.116 & 0.086 & 0.226 \\
\hline Sampling time & $0.585^{\circ}$ & 0.195 & $0.930^{\cdots}$ \\
\hline
\end{tabular}

Table 4. Spearman's rank coefficients of correlation between biogenic sulfur, different biological variables and sampling time under the reduced UVR regime for the whole duration of the experiment DMSP $_{\mathrm{p}}, \mathrm{DMSP}_{\mathrm{d}}, \mathrm{DMS}, \mathrm{chl} a$ and bacterial abundance, $\mathrm{n}=14$; for the other variables, $\mathrm{n}=10$ ). $\cdot 0.01<\mathrm{p} \leq$ $0.05, \cdots 0.001<\mathrm{p} \leq 0.01, \cdots \mathrm{p} \leq 0.001$

\begin{tabular}{|c|c|c|c|}
\hline Reduced UVR & $\mathrm{DMSP}_{\mathrm{p}}$ & $\mathrm{DMSP}_{d}$ & DMS \\
\hline DMSP $_{d}$ & -0.464 & & \\
\hline DMS & $0.869^{\cdots}$ & -0.337 & \\
\hline Chl a & $0.757^{\cdots}$ & -0.101 & $0.693^{\cdots}$ \\
\hline Total phytoplankton & $0.806^{\cdots}$ & -0.370 & $0.796^{\circ}$ \\
\hline Flagellates & $0.879^{\cdots}$ & $-0,382$ & $0.790^{\circ}$ \\
\hline Dinoflagellates & 0.644 & -0.055 & 0.644 \\
\hline Diatoms & 0.430 & -0.491 & 0.395 \\
\hline Cryptomonas spp. & $0.794^{\cdots}$ & -0.382 & $0.833^{\cdots}$ \\
\hline Katodynium spp. & 0.588 & -0.055 & 0.644 \\
\hline Thalassiosira spp. & 0.576 & $-0.685^{\circ}$ & $0.657^{\circ}$ \\
\hline Bacteria & 0.206 & 0.287 & 0.114 \\
\hline Ciliates & 0.345 & -0.370 & 0.438 \\
\hline Sampling time & $0.983^{\cdots}$ & 0.416 & $0.847^{\cdots}$ \\
\hline
\end{tabular}


DMSP $_{\mathrm{d}}$ concentrations measured under natural and reduced light regimes increased during the first day at similar rates of 1.30 and $1.25 \mathrm{nmol} \mathrm{l}^{-1} \mathrm{~h}^{-1}$, respectively (Fig 5b, Table 2). During the second day, DMSP $\mathrm{d}_{\mathrm{d}}$ varied similarly under both light regimes up to the last $6 \mathrm{~h}$ of experiment (Fig. 5b). At the end of the experiment, DMSP $_{d}$ concentrations in the microcosms exposed to the natural light increased by almost a factor of 3 , reaching a value of $130 \mathrm{nmol} \mathrm{I}^{-1}$ (Fig. 5b). During the same period, DMSP only reached $40 \mathrm{nmol} \mathrm{l}^{-1}$ under reduced UVR (Fig. 5b).

In contrast to DMSP and DMSP $\mathrm{D}_{\mathrm{d}}$, DMS concentrations measured under reduced UVR increased 4 times more rapidly $\left(0.58 \mathrm{nmol}^{-1} \mathrm{~h}^{-1}\right)$ over the first $24 \mathrm{~h}$ than those measured under the natural light regime $(0.15 \mathrm{nmol}$ $\mathrm{l}^{-1} \mathrm{~h}^{-1}$ ) (Fig. 5c, Table 2). During the second day, DMS levels in the microcosms exposed to the natural light continued to increase until $36 \mathrm{~h}$, then decreased during the last $6 \mathrm{~h}$ of the experiment (Fig $5 \mathrm{c}$ ). Under reduced UVR, DMS concentrations stabilized around $25 \mathrm{nmol} \mathrm{l}^{-1}$, but always remained higher than those measured under the natural light regime (Fig. 5c). In all microcosms, the concentration of DMS was strongly correlated with the chlorophyll a concentration and the abundances of flagellates and Cryptomonas spp. (Tables $3 \& 4$ )

\section{Variations in $\operatorname{DMSP}_{\mathrm{p}} /$ chlorophyll $a$ and $\operatorname{DMSP}_{\mathrm{p}} /$ total algal cell number ratios}

Fig. 6 presents the temporal variations of DMSP $_{p}$ ' chl $a$ and $\mathrm{DMSP}_{\mathrm{p}} /$ total algal cell number ratios. Under natural light regime, these 2 ratios increased during the first $6 \mathrm{~h}$, then decreased gradually from 160 to 60 nmol per $\mu \mathrm{g}$ chl $a$ and from 0.40 to 0.11 pmol per algal cell number, respectively (Fig. 6a, b). DMSP $/$ /chl $a$ and $\mathrm{DMSP}_{p} /$ total algal cell number ratios were significantly influenced by reduced UVR (Table 1 ). The 2 ratios evolved similarly under both light conditions during the first day (Fig. 6a, b). After 24 h, DMSP $/$ chl a and $\mathrm{DMSP}_{\mathrm{p}}$ /total algal cell number ratios increased from 135 to $172 \mathrm{nmol}$ per $\mu \mathrm{g}$ chrl $a$ and 0.21 to $0.38 \mathrm{pmol}$ per algal cell, respectively, under reduced UVR (Fig. 6a, b).

\section{Variations in bacterial and ciliate abundances}

Fig. 7 presents the temporal changes in bacterial and ciliated protozoan (the dominant group of zooplankton) abundances. Bacterial number under both treatments varied between $1.25 \times 10^{9}$ and $2.40 \times 10^{9}$ cells $l^{-1}$ (Fig. 7a). The bacterial abundance was maximum for each day at 18:00 h (18 and $42 \mathrm{~h}$ ) (Fig. $7 \mathrm{a}$ ). The reduced UVR had no significant effect on the bacterial abun-
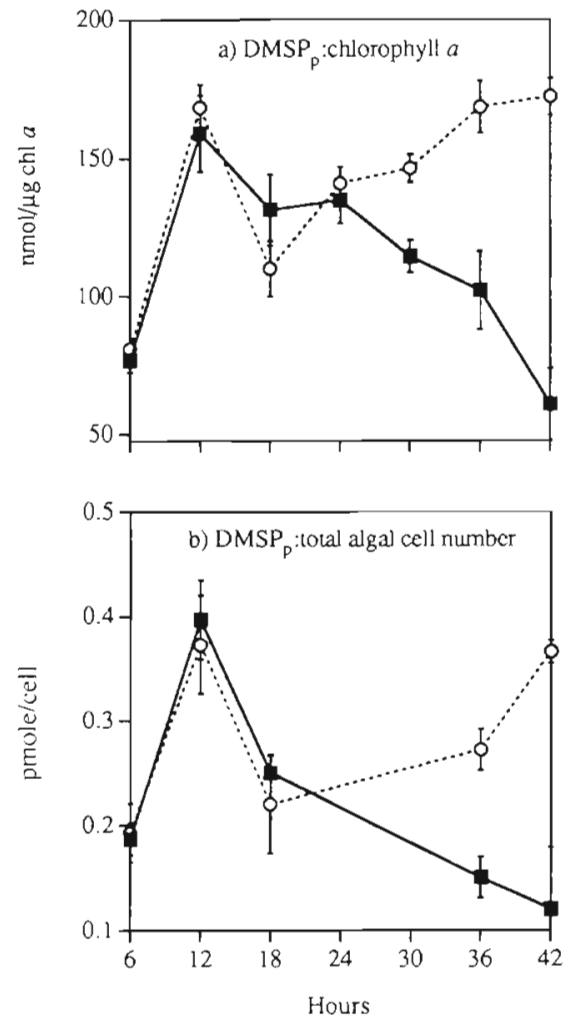

Fig. 6. Temporal variations of (a) DMSP per chlorophyll $a$ and (b) DMSP per total algal cell number under natural (a) and reduced (o) UVR (average \pm standard deviation of duplicates)

dance (Table 1). During the experiment, ciliates numbers under natural light and reduced UVR regimes varied between $3 \times 10^{3}$ and $9 \times 10^{3}$ cells $1^{-1}$ (Fig. 7 b). The ciliate abundance was not influenced by reduced UVR (Table 1).

\section{DISCUSSION}

Our experiments were conducted under typical summer light conditions with a clear sky in the study area. Incident UV-B varied between 0.02 and $0.95 \mu \mathrm{E} \mathrm{m}^{-2} \mathrm{~s}^{-1}$ and the UV-B/PAR ratio varied from 0.0003 to 0.00115 . These values are similar to that of 0.2 to $1 \mu \mathrm{E} \mathrm{m}^{-2} \mathrm{~s}^{-1}$ and 0.0005 to 0.0008 obtained by Ferreyra (1995) on the south shore of the Lower St. Lawrence Estuary in August 1993. However, the incident UV-B and UV-B/PAR ratio at our sampling site were much smaller than values of 0.01 to $10 \mu \mathrm{E} \mathrm{m}^{-2} \mathrm{~s}^{-1}$ and 0.002 to 0.008 observed by Bothwell et al. (1993) at South Thompson River in British Colombia at a similar latitude $\left(50^{\circ} 49^{\prime} \mathrm{N}\right)$. Despite the lower UVR prevailing during our experiment, direct effects of UVR diminution were observed on the net production of DMS and on the DMSP cellular contents of phytoplankton. 

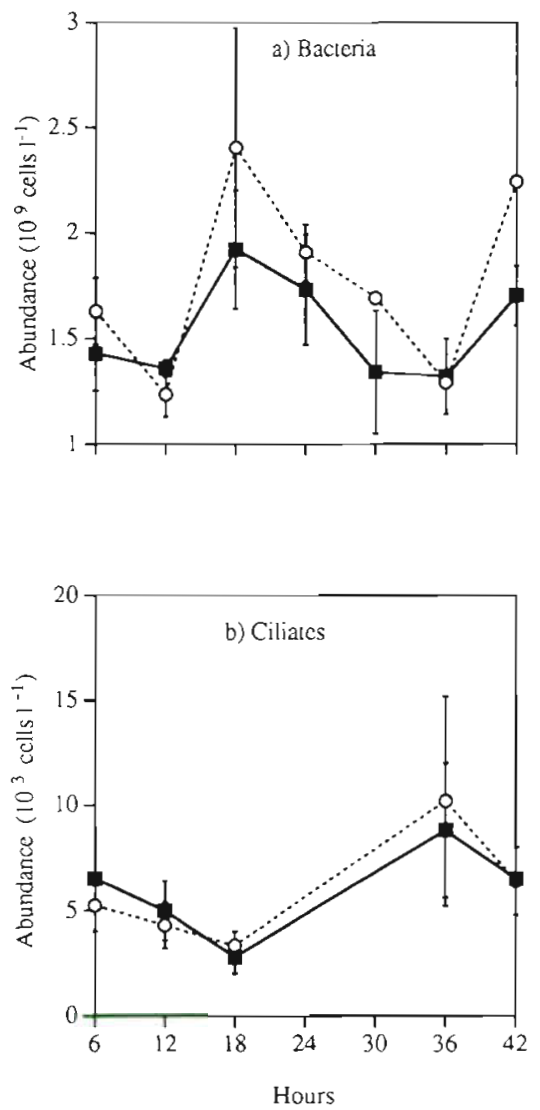

Fig. 7 Temporal variations of (a) bacterial abundance and (b) ciliate abundance under natural ( $)$ and reduced (o) UVR (average \pm standard deviation of duplicates)

During our study, the microalgal community was dominated by small flagellates and dinoflagellates which represented, on average, 60 and $30 \%$ of total algal cell number, respectively. Diatoms represented only 6 to $20 \%$ of the total phytoplankton abundance. The specific composition of phytoplankton was typical of that generally observed in the Lower St. Lawrence Estuary in midsummer (Levasseur et al. 1984). Under natural and reduced UVR, the phytoplankton dynamics were characterized by a gradual increase in algal biomass and total cell abundance (Fig. 4a, b) accompanied by a decrease in nutrient concentrations (nitrate + nitrite and phosphate) (Fig. 3b, c). The abundance of the different phytoplankton taxa (flagellates, dinoflagellates and diatoms) evolved in a similar manner under both light regimes during the whole experiment (Fig. 4c, e, f). After $2 \mathrm{~d}$, there was no important change in taxonomic composition of phytoplankton under reduced UVR. This is not surprising since a change in phytoplankton composition (i.e. algal succession) in response to a modification of the physico-chemical environment generally accurs after a week or more (Harris 1980), a period longer than the duration of our experiment.

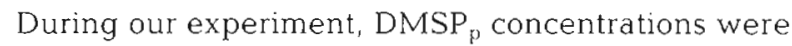
strongly correlated with flagellate abundance, more particularly with Cryptomonas spp. (Tables 3 \& 4). These results agree with those of Gibson et al. (1996), who found a strong correlation between the cellular contents of DMSP $_{\mathrm{p}}$ and Cryptomonas criophyllum abundance in antarctic waters. Despite the fact that species composition of phytoplankton remained relatively stable during the experiment, $\mathrm{DMSP}_{\mathrm{p}}$ concentrations under reduced UVR increased after $24 \mathrm{~h}$ as compared to those measured under natural light conditions (Fig. 5a). Since we observed no significant effect of the light regime on phytoplankton cell abundance, the increase in DMSP under reduced UVR most probably results from a change in DMSP cellular content. These results suggest that a reduction of UVR may enhance the accumulation of DMSP in microalgal cells. This accumulation can result from an increase in the cellular synthesis rate of DMSP. DMSP synthesis depends partly on the availability of its precursor, methionine (Andreae 1986). The metabolism of this amino acid involves ATP, membrane bounded proteins and enzymes (Andreae 1990). It has been shown that the synthesis of these compounds is negatively impacted by UVR (Döhler 1985, Vosjan et al. 1990). In the north Pacific Ocean, Goes et al. (1995) showed that exposure of natural phytoplankton populations to UVR led to a marked decline in the overall rate of carbon incorporated into amino acids and a reduction in the pool size of total cellular amino acids. At stations where flagellates were abundant, they also noted a marked decrease in the synthesis of methionine in the presence of UVR. These results suggest that a reduction in UVR can favour methionine synthesis and, therefore, DMSP synthesis in microalgae. The DMSP accumulation observed in phytoplankton under reduced UVR could also result from a decrease in DMSP excretion rate

During the last $6 \mathrm{~h}$ of the experiment, DMSP $\mathrm{d}$ concentrations under reduced UVR became significantly lower compared to those measured under natural light

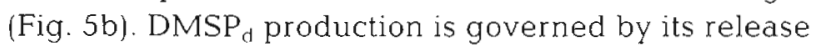
rate in the seawater (by algal senescence, zooplankton grazing, and excretion) and its bacterial degradation rate (Dacey \& Wakeham 1986, Nguyen et al. 1988, Kiene \& Service 1991, Matrai \& Keller 1994). A UVinduced change in these rates may have been responsible for the accumulation of $\mathrm{DMSP}_{d}$ at the end of the experiment in the natural light microcosms. However, we detected no effect of reduced UVR on total bacterial number or on ciliated protozoan abundance, the main potential grazers in the microcosms.

The reduction of UVR had a strong and rapid impact on DMS. Indeed, reduced UVR caused an increase in DMS concentrations in microcosms during the first day 
(Fig 5c). During this day, the accumulation rate of DMS under reduced UVR was 4 times greater than under natural light conditions (Table 2). During the second day, DMS levels in microcosms exposed to reduced UVR stabilized around $25 \mathrm{nmol} \mathrm{l}^{-1}$ (Fig. 5c). This suggests that a new balance between production and sink processes of DMS was established after $24 \mathrm{~h}$. However, concentrations of DMS stayed higher under reduced UVR than under the natural light regime.

During the first $24 \mathrm{~h}$, the increase in the DMS accumulation rate under reduced UVR may have resulted from an increase in the DMS production rate or a decrease in the DMS loss rate. Our results demonstrated that reduced UVR had no effect on $\mathrm{DMSP}_{\mathrm{p}}$ and DMSP $_{d}$, the precursors of DMS, during the first day. Consequently, the rapid accumulation of DMS in microcosms exposed to reduced UVR probably results from a decrease in DMS loss rate. Ventilation, bacterial degradation and photooxidation are the principal sinks for DMS (Brimblecombe \& Shooter 1986, Zeyer et al. 1987, Gibson et al. 1990, Kiene \& Bates 1990, Malin et al. 1993, Kieber et al. 1996). During our experiment, microcosms were covered with filters and submitted to the same mixing conditions before sampling. Consequently, it can be assumed that ventilation made a similar contribution to the DMS sink under both light regimes. Bacterial degradation plays an important role in the marine DMS cycle (Kanagawa \& Kelly 1986 , Suylen et al. 1986, Zeyer et al. 1987, Kwint \& Kramer 1995). During this study, reduced UVR had no effect on the bacterial dynamics (Fig. 7a, Table 1). Since the activity of the bacteria which specifically degrade DMS was not measured, the possibility that reduced UVR can cause an inhibition of DMS-consuming bacterial activity cannot be completely eliminated. Light can also oxidize DMS into dimethylsulfoxide or other products (Brimblecombe \& Shooter 1986, Kieber et al. 1996). Hence, the increase in DMS accumulation rate under reduced UVR can result from a decrease in DMS photooxidation rate. This is consistent with laboratory experiments conducted on surface seawater samples collected in the equatorial Pacific Ocean which show that maximal rates of DMS photolysis occur in the UV$B$ range and for wavelengths between 380 and $460 \mathrm{~nm}$ (Kieber et al. 1996). When these rates are normalized to average springtime solar irradiance incident at the sea surface at the sampling site, Kieber et al. (1996) concluded that photolysis of DMS in seawater occurs predominantly between 380 and $460 \mathrm{~nm}$. In the present study, the UF3 filters cut out wavelengths of 400 nm and below, so that DMS photolysis may have been reduced. In coastal waters, the photolysis of DMS by UVR will probably be limited to the upper few meters of the euphotic layer since UVR is rapidly absorbed by water molecules (Müller-Niklas et al. 1995).
In summary, the results of this study show that natural UVR, even at low levels, can affect the DMSP/DMS dynamics in seawater. Reduced UVR effects were observed at 2 temporal scales. At short time scales $(<24 \mathrm{~h}$ ), reduced UVR favors DMS accumulation, probably by decreasing its removal (photolysis and/or biological consumption). At long time scales $(>24 \mathrm{~h})$, it increases algal DMSP content, probably by enhancing the synthesis and/or by decreasing the metabolic excretion of DMSP.

Acknowledgements. This research was supported by grants from FODAR (Fonds pour le développement et l'avancement de la recherche, Université du Québec) to M.G. and S.D., NSERC individual grants to M.G., M.L. and S.D., Fonds FCAR of Québec to M.G. and by financial help from the Maurice Lamontagne Institute (Department of Fisheries and Oceans Canada) provided to M.L. International collaboration was made possible by NATO collaborative research grant (No. CRG 950139) to S.D. and P.M. A.S. received a post-graduate scholarship from Programme canadien de bourses de la Francophonie. We thank I. Schloss and A. Bélanger for field and laboratory assistance; P. Marsot and S. Roy for providing the nutrients and chlorophyll data, respectively; D. Bird, G Cantin and 4 anonymous reviewers for useful suggestions This is a contribution to the research programmes of the G.R.E.C (Groupe de recherche en environnement cottier) and of the Maurice Lamontagne Institute (Department of Fisheries and Oceans\}.

\section{LITERATURE CITED}

Anderson JG, Toohey DW, Brune WH (1991) Free radicals within the Antarctic vortex: the role of CFCs in Antarctic ozone loss. Science 251:39-46

Andreae MO (1986) The ocean as source of atmospheric sulfur compounds. In: Buat-Ménard P (ed) The role of air-sea exchange in geochemical cycling. D Reidel Publ Co, Dordrecht, p 331-362

Andreae $\mathrm{MO}$ (1990) Ocean-atmosphere interactions in the global biogeochemical sulfur cycle. Mar Chem 30:1-29

Belviso S, Buat-Ménard P, Putaud JP, Nguyen BC, Claustre H, Neveux J (1993) Size distribution of dimethylsulfoniopropionate (DMSP) in areas of the tropical northeastern Atlantic Ocean and the Mediterranean Sea. Mar Chem 44: $55-71$

Belviso S, Kim SK, Rassoulzadegan F, Krajka B, Nguyen BC, Mihalopoulos N, Buat-Ménard P (1990) Production of dimethylsulfonium propionate (DMSP) and dimethylsulfide (DMS) by a microbial food web. Limnol Oceanogr 35: $1810-1821$

Bidigare RR (1989) Potential effects of UV-B radiation on marine organisms of the southern Ocean: distributions of phytoplankton and krill during austral spring. Photochem Photobiol 40:469-477

Bothwell ML, Sherbot DMJ, Pollock CM (1994) Ecosystem response to solar ultraviolet- $B$ radiation: influence of trophic-level interactions. Science 265:97-100

Bothwell ML, Sherbot D, Roberg AC, Daley RJ (1993) Influence of natural ultraviolet radiation on lotic periphytic diatom community growth, biomass accrual and species composition: short-term versus long-term effect. J Phycol $29: 24-35$ 
Brimblecombe P, Shooter D (1986) Photo-oxidation of dimethylsulphide in aqueous solution. Mar Chem 19: $343-353$

Cantin $G$, Levasseur M, Gosselın M, Michaud S (1996) Role of zooplankton on the mesoscale distribution of surface dimethylsulfide concentrations in the Gulf of St. Lawrence. Mar Ecol Prog Ser. 141:103-117

Challenger F, Simpson Ml (1948) Studies in biological methylation. Part XII. A precursor of the dimethyl sulphide evolved by Polysiphonia fastigata dimethyl-2-carboxyethyl-sulphonium hydroxıde and its salts. J Chem Soc 3:1591-1597

Charlson RJ, Lovelock JE, Andreae MO, Warren SG (1987) Oceanic phytoplankton, atmospheric sulphur, cloud albedo and climate Nature 326:655-661

Crocker KM, Ondrusek ME, Petty RL, Smith RC (1995) Dimethylsulfide, algal pigments and light in an Antarctic Phaeocystis sp. bloom. Mar Biol 124:335-340

Cullen JJ, Neale PJ, Lesser MP (1992) Biological weighting function for the inhibition of phytoplankton photosynthesis by ultraviolet radiation. Science 258:646-650

Dacey JWH, Wakeham SG (1986) Oceanic dimethy]sulphide production during zooplankton grazing on phytoplankton Science 233:1314-1316

Damkaer DM, Dey DB (1983) UV damage and photoreactivation potentials of larval shrimp, Panalus platyceros, and adult euphausiids, Thysanoessa raschii. Oecologia 60 $169-175$

Dey DB, Damkaer DM, Heron GA (1988) UV-B dose/doserate responses of seasonally abundant copepods of Puget Sound. Oecologia 76:321-329

Dickson DMJ, Kirst GO (1986) The role of dimethylsulfoniopropionate, glycine betaine and homarine in the osmoacclimatation of Platymonas subcordiformis. Planta 167 $536-543$

Dickson DMJ, Kirst GO (1987a) Osmotic adjustment in marine eukaryotic algae: the role of inorganic sons, quaternary ammonium, tertiary sulphonium and carbohydrate solutes. I. Diatoms and rhodophyte. New Phytol 106: $645-655$

Dickson DMJ, Kirst GO (1987b) Osmotic adjustment in marine eukaryotic algae: the role of inorganic ions, quaternary ammonium, tertiary sulphonium and carbohydrate solutes. 11. Prasinophytes and haptophytes. New Phytol 106:657-666

Döhler G (1985) Effect of UV-B radiation (290-320 nm) on the nitrogen metabolism of several marine diatoms. J Plant Physiol 118:391-400

Ferreyra GA (1995) Effets du rayonnement ultraviolet sur le plancton des régions froides tempérées et polaires. Thèse de doctorat, Département d'océanographie, Université du Québec à Rimouski

Gibson JAE, Garrick RC, Burton HR, McTaggart AR (1990) Dimethylsulfide and the algae Phaeocystus pouchetii in antarctic coastal waters. Mar Biol 104:339-346

Gibson JAE, Swadling KM, Burton HR (1996) Acrylate and dimethylsulfoniopropionate (DMSP) concentrations during an antarctic phytoplankton bloom. In: Kiene RP, Visscher PT, Keller MD, Kirst GO (eds) Biological and environmental chemistry of DMSP and related sulfonium compounds. Plenum Press, New York, p 213-222

Goes JI, Handa N, Taguchi S, Hama T, Saito H (1995) Impact of UV radiation on the production patterns and composition of dissolved free and combined amino acids in marine phytoplankton. J Plankton Res 17:1337-1362

Harris GP (1980) Spatial and temporal scales in phytoplankton ecology: mechanisms, methods, models and manage- ment. Can J Fish Aquat Sci 37:877-900

Hegg DA, Radke LF, Hobbs PV (1991) Measurements of aitken nuclei and cloud condensation nuclei in the marine atmosphere and their relation to the DMS-cloud-climate hypothesis. J Geophys Res 96:18727-18733

Herndl G. Muller-Nicklas G. Frick J (1993) Major role of ultraviolet-B in controlling bacterioplankton growth in the surface layer of the ocean. Nature 361:717-718

Kanagawa T, Kelly DP (1986) Breakdown of dimethyl sulphide by mixed cultures and by Thiobacillus thioparus. FE.1S Microbiol Lett 34:13-19

Karentz D. Cleaver JE, Mitchell DL (1991) Cell survival characteristics and molecular responses of antarctic phytoplankton to ultraviolet-B radiation. J Phycol 27:326-341

Karsten U, Wiencke C, Kirst GO (1990) The effect of light intensity and daylength on the dimethylsulphoniopropionate (DMSP) content of marine green macroalgae from Antarctica. Plant Cell Environ 13:989-993

Karsten U, Wiencke C, Kirst GO (1992) Dimethylsulphoniopropionate (DMSP) accumulation in green macroalgae from polar to temperate regions: interactive effects of light versus salinity and light versus temperature. Polar Biol 12 : 603-607

Keller MD (1991) Dimethyl sulfide production and marine phytoplankton: the importance of species composition and cell size. Biol Oceanogr 6:375-382

Keller MD, Bellows WK, Guillard RRL (1989a) Dimethyl sulfide production and marıne phytoplankton: an additional impact of unusual blooms. In: Cosper EM, Bricelj VM, Carpenter EJ (eds) Novel phytoplankton blooms. Springer-Verlag, Berlin, p 101-115

Keller MD, Bellows WK, Guillard RRL (1989b) Dimethyl sulfide production in marine phytoplankton. In: Saltzman ES, Cooper WJ (eds) Biogenic sulfur in the environment. Am Chem Soc, Washington, DC, p 167-182

Kerr JB, McElroy CT (1993) Evidence for large upward trends of ultraviolet-B radiation linked to ozone depletion. Science 262:1032-1034

Kieber DJ, Jiao J, Kiene RP, Bates TS (1996) Impact of dimethylsulfide photochemistry on methyl sulfur cycling in the equatorial Pacific Ocean. J Geophys Res 101 (C2) $3715-3722$

Kiene RP (1992) Microbial sources and sinks for methylated sulfur compounds in the marine environment. In: Murrell JC, Kelly DP (eds) Microbial growth on $C_{1}$ compounds intercept Ltd, Andover, p 15-33

Kiene RP. Bates TS (1990) Biological removal of dimethyl suiphide from seawater. Nature 345:702-705

Kiene RP, Service SK (1991) Decomposition of dissolved DMSP and DMS in estuarine waters: dependence on temperature and substrate concentration. Mar Ecol Prog Ser 76:1-11

Kwint, RLJ, Kramer, KJM (1995) Dimethylsulphide productjon by plankton communities. Mar Ecol Prog Ser 121 $227-237$

Lawrence, $M G$ (1993) An empirical analysis of the strength of the phytoplankton-dimethylsulfide-cloud-climate feedback cycle. J Geophys Res 98:20663-20673

Leck C, Bågander LE (1988) Determination of reduced sulfur compounds in aqueous solutions using gas chromatography flame photometric detection. Anal Chem 60: $1680-1683$

Leck C, Larsson U, Bågander LE, Johansson S, Hajdu S (1990) Dimethyl sulfide in Baltic Sea: annual variability in rela. tion to biological actuvity. J Geophys Res 95:3353-3364

Levasseur M, Gosselin M. Michaud S (1994a) A new source of dimethylsulfide (DMS) for the arctic atmosphere: ice 
diatoms. Mar Biol 121:381-387

Levasseur M, Keller MD, Bonneau E, D'amours D, Bellows WK (1994b) Oceanographic basis of DMS-related atlantic cod (Gadus morhua) fishery problem: blackberry feed Can J Fish Aquat Scl 51:881-889

Levasseur M, Therriault JC, Legendre L (1984) Hierarchical control of phytoplankton succession by physical factors. Mar Ecol Prog Ser 19:211-222

Lindell MJ, Granéli W, Tranvik LJ (1995) Enhanced bacterıal growth in response to photochemical transformation of dissolved organic matter. Limnol Oceanogr 40:195-199

Malin G, Turner S, Liss P, Holligan P, Harbour D (1993) Dimethylsulphide and dimethylsulphoniopropionate in the northeast Atlantic during the summer coccolithophore bloom. Deep Sea Res 40:1487-1508

Matrai PA, Keller MD (1993) Dimethylsulfide production in large scale coccolithophore bloom in the Gulf of Maine. Cont Shelf Res 13:831-843

Matrai PA, Keller MD (1994) Total organic sulfur and dimethylsulfoniopropionate in marine phytoplankton: intracellular variation. Mar Biol 119:61-68

Müller-Niklas G, Heissenberger, Puskaric S, HerndI GJ (1995) Ultraviolet-B radiation and bacterial metabolism in coastal waters. Mar Ecol Prog Ser 9:111-116

Nguyen BC, Belviso S, Mihalopoulos N, Gostan J, Nival P (1988) Dimethylsulfide production during natural phytoplanktonic blooms. Mar Chem 24:133-141

Porter KG, Feig YS (1980) The use of DAPI for identifying and counting aquatic microflora. Limnol Oceanogr 25:943-948

Reed RH (1983) Measurement and osmotic significance of dimethylsulfonjopropionate in marine macroalgae. Mar Biol Lett 4:173-181

Smith R C, Prézelin BB, Baker KS, Bidıgare RR, Boucher NP, Coley T, Karentz D, MacIntyre S, Matlick HA, Menzies D, Ondrusek M. Wan Z, Waters KJ (1992) Ozone depletion: ultraviolet radiation and phytoplankton biology in antarctic waters. Science 255:952-959

Strickland JDH, Parsons TR (1972) Practical handbook of seawater analysis, 2nd edn. Bull Fish Res Board Can 167 : $1-310$

Suylen GMH, Stefess GC, Kuenen JG (1986) Chemolithotrophic potential of a Hyphomicrobium species, capable of growth on methylated sulfur compounds. Arch

This article was submitted to the editor
Microbiol 146:192-198

Throndsen J (1978) Preservation and storage. In: Sournia A (ed) Phytoplankton manual. The UNESCO Press, Paris, p $69-74$

Turner SM, Malin G, Liss PS, Harbour DS, Holligan PM (1988) The seasonal variation of dimethyl sulfide and dimethylsulfoniopropionate concentrations in nearshore waters. Limnol Oceanogr 33:364-375

Utermöhl N (1.931) Neue Wege in der quantitativen Erfassung des Planktons. Verh Int Verein Theor Angew Limnol 5: $567-596$

Vairavamurthy A, Andreae MO, Iverson RL (1985) Biosynthesis of dimethylsulfide and dimethylpropiothetin by $\mathrm{Hy}$ menomonas carterae in relation to sulfur source and salinity variations. Limnol Oceanogr 30:59-70

Vetter YA, Sharp J (1993) The influence of light intensity on dimethylsulfide production by a marine diatom. Limnol Oceanogr 38:419-425

Vosjan JH, Döhler G, Nieuwland G (1990) Effect of UV-B irradiance on the ATP content of microorganisms of the Weddell Sea (Antarctica). Neth J Sea Res 25:391-393

Watson R (1988) Ozone trends panel: executive summary. NASA, Washington, DC

Winer BJ (1971) Statistical principles in experimental design. McGraw-Hill Book Company, New York

Wolfe GV, Kiene RP (1993) Effects of methylated, organic and inorganic substrates on microbial consumption of dimethyl sulfide in estuarine waters. Appl Environ Microbiol 59:2723-2726

Wolfe GV, Sherr EB, Sherr BF (1994) Release and consumption of DMSP from Emiliania huxleyi during grazing by Oxyrrhis marina. Mar Ecol Prog Ser 11:111-119

Wright SW, Jeffrey SW, Mantoura RFC, Llewellyn CA, Bjornland T, Repeta D, Welschmeyer N (1991) Improved HPLC method for the analysis of chlorophylls and carotenoids from marine phytoplankton. Mar Ecol Prog Ser 77: $183-196$

Zar H (1984) Biostatistical analysis. Prentice-Hall, Englewood Cliffs

Zeyer J, Eicher P, Wakeham SG, Schwartzenbach RP (1987) Oxidation of dimethyl sulfide to dimethyl sulfoxide by phototrophic purple bacteria. Appl Environ Microbiol 53 2026-2032

Manuscript first received: August 5, 1996

Revised version accepted: February 7, 1997 